\title{
Subungual epidermoid carcinoma
}

Subungual epidermoid karsinom

\author{
Alper Çelik', Recep Çetin' ${ }^{1}$ Işın Pak², Abdullah Çetin
}

'Ankara Onkoloji Hastanesi 1. Genel Cerrahi Kliniği, Ankara

${ }^{2}$ Ankara Onkoloji Hastanesi Patoloji Kliniği, Ankara
Received: 25.10.2005 • Accepted: 25.04.2006

Corresponding author

\section{Dr. Alper Celik}

Batısitesi Mh. 5. Cd. 280 Sk. No: 6/3 06370 Mesa, Batıkent / Ankara

Phone $\quad:+90(0312) 2503853$

Fax $\quad:+90(0312) 3454979$

GSM : : $\quad$ +90 (0532) 7059540

E-mail adress : doktoralper@hotmail.com
Epidermoid carcinoma of the subungual area is a rare variant of the tumours of the nail bed, and may mimic infectious diseases. Different histological variants of subungual tumours including pleomorphic fibroma, chondroma, glomus tumour, perineurinoma, and melanoma have been reported (1-5). Only 12 cases of subungual squamous carcinoma have been reported to date (6-17). We hereby present a case of subungual invasive epidermoid carcinoma that has previously been treated as paronychia leading to a delay in diagnosis and treatment. Patient's informed consent has been taken for this case report.

Key words: subungual, epidermoid, squamous, carcinoma

Tırnak altında lokalize epidermoid karsinom tırnak yatağı tümörlerinin oldukça nadir görülen bir alt tipidir ve infeksiyöz hastalıkları taklit edebilir. Tırnak altının pleomorfik fibroma, kondroma, glomus tümörü, perinörinoma ve melanoma gibi değişik histolojik alt tipleri bildirilmiştir (1-5). Günümüze kadar sadece 12 subungual yassı hücreli karsinom olgusu bildirilmiştir (6-17). Bu bildiride paronişi tanısı ile tedavi edilerek tanı ve tedavide gecikmeye neden olunmuş bir subungual invaziv epidermoid karsinom olgusu sunulmuştur. Olgu sunumu için hastadan sözel onay alınmıştır.

Anahtar sözcükler: tırnak altı, epidermoid, skuamöz, karsinom

\section{Case Report}

A 73 years old male presented in our department with a dystrophic lesion on his left thumb nail persisting for 16 years (Figure 1). He was previously treated with local antibiotics, and repeated curettages. Incisional biopsy performed at another medical centre revealed epidermoid carcinoma. Preoperative screening with chest $\mathrm{x}$-ray and abdominal ultrasound was normal. An ipsilateral axillary lymph node with a diameter of 1.7 centimetres and possible reactive features was detected by axillary ultrasound. Preoperative x-ray of the terminal phalanx was normal. Interphalangeal amputation combined with axillary lymph node dissection was applied.

Macroscopic examination showed a $3 \times 2.5 \times 2 \mathrm{~cm}$, terminal phalangeal amputation material, with a $1.7 \times 0.8 \mathrm{~cm}$ deformated nail, and a $1.5 \times 1 \mathrm{~cm}$ creamywhite, irregular area on nail plate. Skin, bone, and interarticular surgical margins were studied. Nail and bone were kept for $30 \%$ acid processing.

Microscopic features were, subepithelial, invasive, solid tumoral tissue related to multilayered squamous epithelia consisting of atypical epithelial cells with vesicular, hyperchromatic nucleus, marked nucleoli, and eosinophilic cytoplasm.

On histological examination, the tumour included irregular nests of epidermal cells that proliferate downward to dermis (Figure 2; 40×, haematoxylin-eosin). The invading tumoral tissue was composed in varying proportions of normal and 


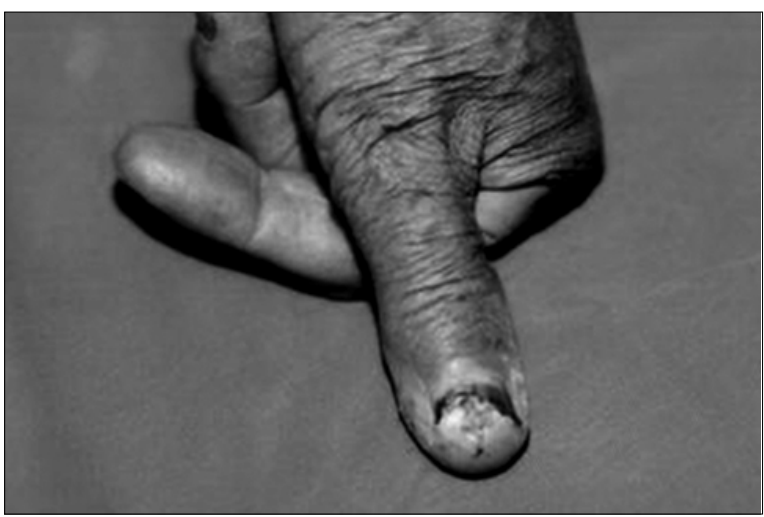

Figure 1. The initial appearance of the dystrophic lesion on the patient's left thumb.

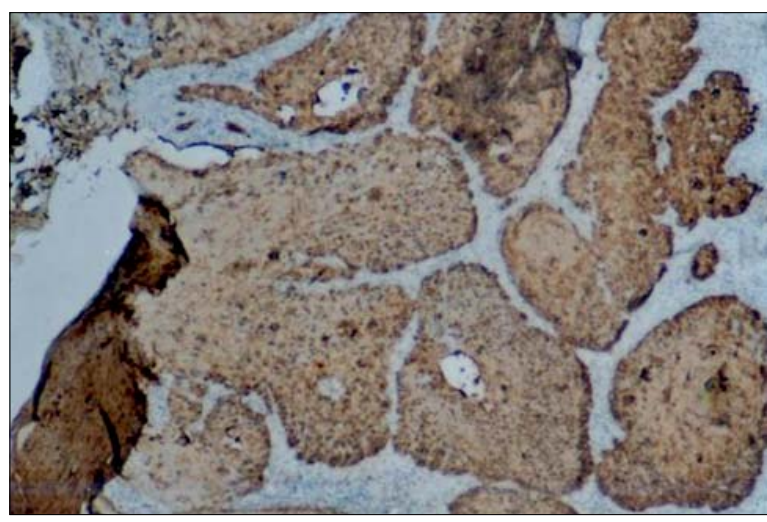

Figure 3. HMWCK (High Molecular Weight Cytokeratin) (Neomarkers, $0.5 \mathrm{ml}$ ) staining was positive $(40 \mathrm{x})$.

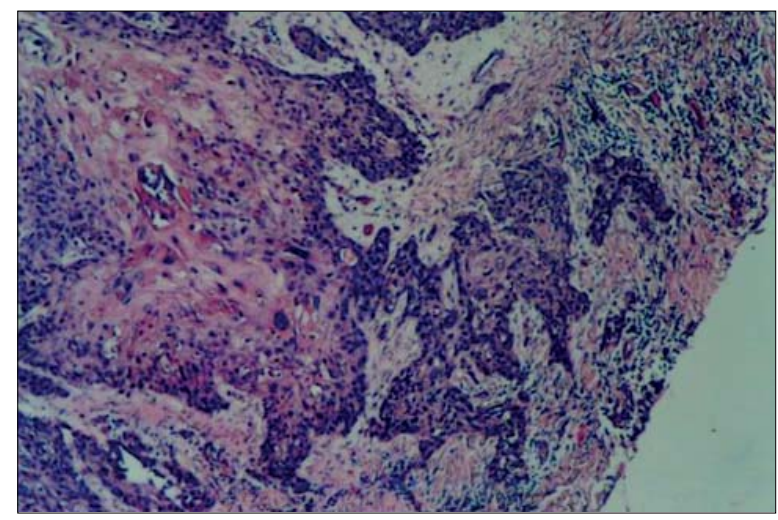

Figure 2. On histological examination, the tumour included irregular nests of epidermal cells

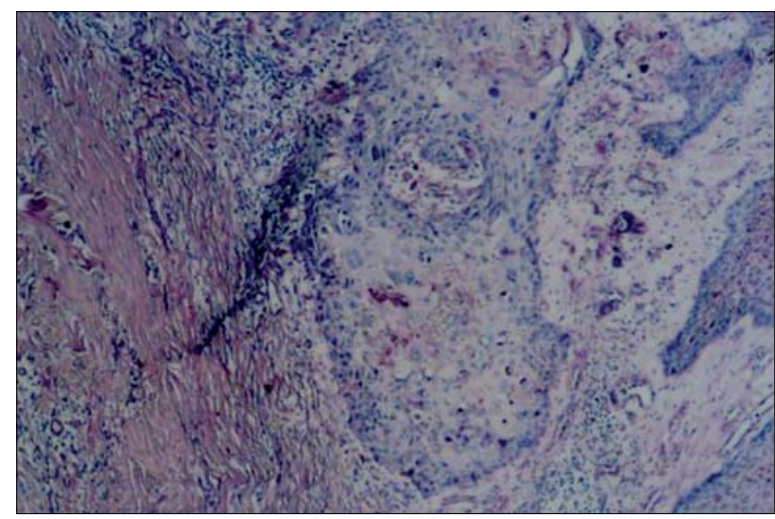

Figure 4. The overlying nail (after acid processing) was invaded by the tumour (40x, haematoxylin-eosin). atypical squamous cells, where areas of basal membrane destruction were detected. Histochemical staining with PAS (Periodic Acid Schiff) was negative. Immunohistochemical staining with collagen type IV, and laminin were negative, but HMWCK (High Molecular Weight Cytokeratin) (Neomarkers, $0.5 \mathrm{ml}$ ) staining was positive (Figure 3; 40×). The overlying nail (often acid processing) was invaded by the tumour (Figure 4; 40x, haematoxylin-eosin). The bony structures were not destructed by the tumour, and all surgical margins were clear. No evidence of metastasis was found in 15 lymph nodes dissected from axilla.

In the postoperative period, the case followed an uncomplicated course, and was discharged on the postoperative $9^{\text {th }}$ day.

\section{Discussion}

Squamous cell carcinoma (SCCa) of the nail bed is a rare entity. Slowly growing forms when combined with subtle signs and reluctance of the physician or the patient might result in a delay of the appropriate treatment. The nail plate is a physical barrier and a patient's resistance to its removal is a physiological barrier to the recognition and treatment of a tumour arising in the nail bed.
Our case experienced a 16-year delay due to inadequate diagnosis, which might be a result of inadequate biopsy specimens, and repeated curettages. Fleckman reported a similar case of epidermoid carcinoma of the nail bed that has been treated as chronic paronychia for 14 years (8). A 40-year delay has also been reported in the literature (10). Dobson and co-workers have also reported a case of squamous carcinoma arising in a psoriatic nail bed, challenging diagnosis, and therapeutic options (15).

Squamous cell carcinoma of the nail bed usually affects older age groups, with male dominancy, and occurs in both thumbs and fingers. In the past, it has been associated with radiation exposure, especially among dentists and physicians (8). Our patient was a farmer, and had no previous history of radiation exposure.

The appearance of a subungual tumour is non-diagnostic. For this reason exploratory nail plate removal with biopsy of the nail bed has been recommended, not only for epidermoid carcinoma, but also for other subungual tumours (9). In order to obtain better results, Mikhail stated that a longitudinal incision through the suspected tumour down to the periosteum provides the best adequacy (7). 
The possibility of malignancy must be encountered among patients with persistent nail abnormality, especially elder male patients, those with a history of previous radiation exposure (8). This arises the importance of anamnesis in correct diagnosis.

In general the presence of a large exophytic mass located at the distal portion of the finger suggests the clinical diagnosis of a squamous carcinoma or an inflammatory process like pyogenic granuloma. Subungual SCCa is usually located at the sulcus of the nail, and presents as a mass under the distal lateral edge of the nail, and a long term history of several years is present. Though, pyogenic granuloma is not a specific subungual lesion. It usually presents as a granulation tissue, the course is usually short, and a history of injury is commonly noted (18). Some patients attribute the onset of their tumors to trauma, but more

\section{References}

1. Hsieh YJ, Lin YC, Wu YH et al.Subungual pleomorphic fibroma. J Cutan Pathol. 2003;30:569-571.

2. Bostanci S, Ekmekci P, Ekinci C et al. Subungual osteochondroma: a case report. Dermatol Surg. 2001;27:591-593.

3. Tomak Y, Akcay I, Dabak N et al. Subungual glomus tumours of the hand: diagnosis and treatment of 14 cases. Scand J Plast Reconstr Surg Hand Surg. 2003;37:121-124.

4. Baran R, Perrin C. Subungual perineurioma: a peculiar location. $\mathrm{Br}$ J Dermatol. 2002;146:125-128.

5. O'Leary JA, Berend KR, Johnson JL et al. Subungual melanoma. Review of 93 cases with identification of prognostic variables. Clin Orthop. 2000;(378):206-212

6. Shapiro L, Baraf CS. Subungual epidermoid cancer and keratoacanthoma. Cancer 1970;25:141-152.

7. Mikhail GR. Subungual epidermoid carcinoma. J Am Acad Dermatol 1984;11:291-298.

8. Fleckman P, Bernstein G, Barker E. squamous cell carcinoma of the nail bed treated as chronic paronychia and wart for fourteen years. Cutis 1985;36:189-191.

9. Shelley ED, Shelley WB. Exploratory nail plate removal as a diagnostic aid in painful subungual tumours: glomus tumour, neurofibroma, and squamous cell carcinoma. Cutis 1986;38:310-312. probably when the lesions are injured they do not heal, and are therefore noticed. The probability of a subungual malignancy should be considered if there is pigmentation of the nail bed, persistent onychia, paronychia, or chronic granulation of the nail bed, unexplained splitting, cracking, or displacement of the nail bed or persistence of a lesion after damage to the nail. If a lesion has not changed remarkably after induction of a treatment for 4 to 6 weeks, it should be biopsied by removing the nail, and taking adequate amount of the mass. The biopsy specimen would better include central and peripheral areas of the lesion because skin cancers might have a lateral growth phase, which might be distinguished with a benign_lesion. Whether if the possibility of malignancy was considered for our patient, and adequate material was obtained for diagnosis, he might have been treated years ago.

10. Hale LR, Dawber RPR. Subungual squamous cell carcinoma presenting with minimal nail changes: a factor in delayed prognosis? Aust J Dermatol 1998;39:86-88.

11. Betti R, Vergani R, Inselvini E et al. Guess what! Subungual squamous cell carcinoma mimicking chronic paronychia. Eur J Dermatol. 2000;10:149-150.

12. Yip KM, Lam SL, Shee BW et al. Subungual squamous cell carcinoma: report of 2 cases. J Formos Med Assoc. 2000;99:646-49.

13. Ryu JS, Cho JW, Moon TH et al. Squamous cell lung cancer with solitary subungual metastasis. Yonsei Med J. 2000;41:666-668.

14. Obiamiwe PE. Subungual squamous cell carcinoma. Br J Plast Surg. 2001;54:631-632.

15. Dobson CM, Azurdia RM, King CM. Squamous cell carcinoma arising in a psoriatic nail bed: case report with discussion of diagnostic difficulties and therapeutic options. Br J Dermatol. 2002;147:144-149.

16. Yaparpalvi R, Mahadevia PS, Gorla GR et al. Radiation therapy for the salvage of unresectable subungual squamous cell carcinoma. Dermatol Surg. 2003;29:294-296.

17. Dominguez-Cherit J, Garcia C, Vega-Memije ME et al. Pseudofibrokeratoma: an unusual presentation of subungual squamous cell carcinoma in a young girl. Dermatol Surg. 2003;29:788-789.

18. Linares MD, Hardisson D, Perna C. Subungual malignant melanoma of the hand: unusual clinical presentation. Scand J Plast Reconstr Surg Hand Surg 1998;32:347-350. 